\title{
Piotr Gradziuk
}

\section{Sprawozdanie z konferencji „Mikroźródła energii odnawialnej jako podstawa energetyki obywatelskiej oraz perspektywy ich rozwoju w Polsce i UE", Grodno k. Międzyzdrojów, 25 czerwca 2016 roku}

Nowym zjawiskiem, które będzie miało istotne znaczenie dla dalszego rozwoju sektora elektroenergetycznego, jest wykorzystanie mikrogeneracji dającej podstawy do rozwoju obywatelskiej czy też komunitariańskiej wizji energetyki, bazującej na inicjatywie obywateli i ich wspólnot. Dostrzegając wagę takich systemów wytwarzania energii elektrycznej, Europejski Fundusz Rozwoju Wsi Polskiej - Counterpart Fund (EFRWP - CP) w partnerstwie z Fundacją Konrada Adenauera, Agencją Rynku Rolnego oraz Bankiem Ochrony Środowiska S.A., pod honorowym patronatem Ministra Rolnictwa i Rozwoju Wsi zorganizował konferencję naukową na temat „Mikroźródła energii odnawialnej jako podstawa energetyki obywatelskiej oraz perspektywy ich rozwoju w Polsce i UE”. Konferencję, która odbyła się 25 czerwca 2016 r. w Centrum Współpracy Międzynarodowej w Grodnie k. Międzyzdrojów, otworzyli Artur Balazs, prezes Kapituły Fundacji EFRWP - CP, oraz Krzysztof Podhajski, prezes Zarządu Fundacji.

Obrady toczyły się w trzech panelach programowych dotyczących: 1) polityki UE wobec rozwoju mikroźródeł energii odnawialnej i energetyki obywatelskiej, 2) polityki i perspektyw rozwoju mikroźródeł na obszarach wiejskich w Polsce oraz 3) instrumentów wspomagania rozwoju mikroźródeł energii odnawialnej na terenach wiejskich.

W referacie otwierającym konferencję wygłaszający go Jerzy Buzek, przewodniczący Komisji ds. Przemysłu, Badań Naukowych i Energii Parlamentu Europejskiego, odniósł się do wyzwań dla sektora energetycznego wynikających z globalnej i europejskiej polityki klimatycznej. Do najważniejszych przedsięwzięć,

Autor jest pracownikiem Instytutu Rozwoju Wsi i Rolnictwa PAN, ul. Nowy Świat 72, 00-330 Warszawa (e-mail: pgradziuk@irwirpan.waw.pl). 
które mogą skutkować bezpośrednim lub pośrednim ograniczeniem emisji gazów cieplarnianych, zaliczył wzrost wykorzystania odnawialnych źródeł energii (OZE). Energetyka odnawialna, poza korzyściami dla środowiska naturalnego, sprzyja też wzrostowi konkurencji na rynku energetycznym. Wpływa na poprawę bezpieczeństwa energetycznego, umożliwiając stabilne, niczym niezakłócone, zróżnicowane pod względem źródeł, dostawy energii o odpowiednich parametrach jakościowych i po społecznie akceptowanych cenach. Dodatkową zaletą mikroźródeł energii odnawialnej jest też wzmocnienie bezpieczeństwa w skali lokalnej, gdyż rozproszona energetyka powoduje mniejsze zakłócenia w przypadku awarii sieci energetycznych czy też u producentów energii. Zmniejsza również koszty wynikające z budowy i eksploatacji linii przesyłowych oraz przyczyniania się do poprawy zaopatrzenia w energię, w szczególności na terenach o słabej infrastrukturze energetycznej, a są to głównie obszary wiejskie. W zwiększeniu wykorzystania OZE upatruje się też czynnika stymulującego rozwój gospodarczy i społeczny. Firmy inwestujące w zieloną energię wprowadzają nowe technologie, tworzą lokalne rynki pracy, wzmacniają rynek usług, przyczyniając się bezpośrednio do wzrostu innowacyjności danej jednostki terytorialnej, promocji jej wizerunku, a w rezultacie do rozwoju lokalnego.

Kolejne dwa referaty (panel I) wygłoszone przez Agnieszką Kaźmierczak (dyrektor w Dyrekcji Generalnej ds. Energii KE) i Shane Sutherland (członek gabinetu Phila Hogana, komisarza ds. rolnictwa i rozwoju wsi KE) dotyczyły roli UE w rozwoju energetyki obywatelskiej na obszarach wiejskich. Autorzy przedstawili także znaczenie tych terenów w realizacji celów UE dotyczących energii odnawialnej. $\mathrm{Na}$ zakończenie tego panelu Franz Fischler (europejski komisarz ds. rolnictwa, rozwoju wsi i rybołówstwa w latach 1995-2004) przedstawił doświadczenia Austrii i innych krajów UE w zakresie wsparcia energetyki obywatelskiej na obszarach wiejskich, ze szczególnym uwzględnieniem biomasy. Jej zasoby są powszechnie dostępne i mogą być używane w procesach bezpośredniego spalania (np. drewno, słoma, osady ściekowe), przetwarzane na paliwa ciekłe (np. estry oleju rzepakowego, alkohol) bądź gazowe (np. biogaz rolniczy, biogaz z oczyszczalni ścieków, gaz wysypiskowy). $\mathrm{Na}$ zakończenie wystąpienia Fischler scharakteryzował obowiązujący w Austrii system wsparcia energetyki odnawialnej.

Panel II poświęcono polityce i perspektywom rozwoju mikroźródeł na obszarach wiejskich w Polsce. Krzysztof Jurgiel (minister rolnictwa i rozwoju wsi) przedstawił możliwości rozwoju energetyki obywatelskiej wynikające z polityki rządu RP wobec obszarów wiejskich, a Krzysztof Tchórzewski (minister energii) najnowsze uregulowania prawne dotyczące energetyki odnawialnej. W obu wystąpieniach wskazywano na rolę odnawialnych źródeł energii dla rozwoju obszarów wiejskich. Tchórzewski zaznaczył, że obecny system wsparcia wykorzystania OZE preferuje technologie, które nie wymagają utrzymywania tzw. gorącej rezerwy w systemie 
dyspozycji mocy, są to między innymi biogazownie oraz instalacje biomasowe lub hybrydowe. Ponadto promowane będą lokalne inicjatywy gospodarcze takie jak spółdzielnie i klastry energetyczne. W znowelizowanej ustawie o odnawialnych źródłach energii z dnia 22 czerwca 2016 r. zrezygnowano z taryf gwarantowanych dla prosumentów utrzymując rozliczenia $\mathrm{w}$ ramach netmeteringu (rozliczania barterowego). Występujące u prosumenta nadwyżki energii elektrycznej będą przeznaczane na pokrycie opłat za usługi dystrybucji i kosztów rozliczeń.

W tej części konferencji wystąpił także Łukasz Hołubowski (prezes Agencji Rynku Rolnego), który dokonał analizy rynku biogazu rolniczego i biokomponentów w Polsce. Wskazał przy tym, że preferowanym kierunkiem rozwoju wykorzystania OZE jest generacja rozproszona oraz zwiększenie udziału wykorzystania produktów ubocznych i odpadów organicznych głównie do wytwarzania biopaliw kolejnych generacji. Stwarza to ogromne szanse dla rolnictwa, w którym więcej niż połowa produkcji globalnej to masa nienadająca się do spożycia. Takie warunki spełnia produkcja biogazu, szczególnie z odchodów zwierzęcych, obornika i odpadów organicznych, których niekontrolowany rozkład jest poważnym źródłem emisji metanu. W latach 2005-2014 jego udział w strukturze pozyskania energii z biomasy zwiększył się z 4,9 do 11,6\%. Według stanu na 18 lutego 2016 r. do rejestru prowadzonego przez prezesa Agencji Rynku Rolnego było wpisanych już 81 biogazowni rolniczych o łącznej wydajności biogazu wynoszącej $335,8 \mathrm{mln}$ $\mathrm{m}^{3} /$ rok i mocy $86,9 \mathrm{MW}_{\mathrm{e}}$. Jednak dalszy rozwój tej branży jest uzależniony od poziomu wsparcia. Obecnie obowiązujący (głównie zielone certyfikaty) okazał się nieskuteczny, gdyż dla większości biogazowni oznacza straty. Głównym celem funkcjonowania biogazowni jest utylizacja uciążliwych dla środowiska substancji, w tym także odpadów z przemysłu mięsnego, mleczarskiego, zakładów zbiorowego żywienia, przeterminowanej żywność i pasz oraz wielu innych substratów, dla których alternatywny sposób zagospodarowania jest bardziej kosztowny i uciążliwy dla środowiska. Powstałą przy tym energię należy traktować jako efekt dodatkowy, otrzymany „przy okazji”. Przy czym dla poprawy efektywności procesu technologicznego może zachodzić konieczność uzupełnienia takiego wsadu kiszonką. O randze tego źródła energii świadczą zapisy w przyjętym przez Radę Ministrów w 2010 r. dokumencie „Kierunki rozwoju biogazowni rolniczych w Polsce w latach 2010-2020"1. Ich realizacja wpłynęłaby na dywersyfikację dostaw gazu, którego realnie dostępny potencjał wynosi $1,7 \mathrm{mld}^{3}$ rocznie, tj. ponad $10 \%$ krajowego zużycia, i mógłby w całości zaspokoić potrzeby odbiorców z terenów wiejskich.

1 „Kierunki rozwoju biogazowni rolniczych w Polsce w latach 2010-2020”, Urząd Rady Ministrów, Warszawa 2010. 
Grzegorz Wiśniewski (prezes Instytutu Energetyki Odnawialnej) wskazał, że mikroźródła i małe źródła energii odnawialnej mogą być ważnym elementem bezpieczeństwa energetycznego obszarów wiejskich i rolnictwa oraz alternatywnym źródłem dochodów rolników. Aby tak się stało, niezbędne jest opracowanie rządowego program rozwoju wykorzystania OZE w rolnictwie i na obszarach wiejskich. Winien być on elementem opracowywanego w ministerstwie rolnictwa „Paktu dla obszarów wiejskich”, rządowego „Planu na rzecz odpowiedzialnego rozwoju", wraz z oceną potrzeb energetycznych rolnictwa i uwzględnieniem różnic regionalnych (w tym obszarów peryferyjnych) polityki energetycznej państwa. Na brak planu działań oraz opóźnienia w działaniach programowych i legislacyjnych dotyczących przygotowania przepisów regulujących wytwarzanie energii ze źródeł odnawialnych wskazywał także Jacek Uczkiewicz (wiceprezes Najwyższej Izby Kontroli). Opóźnione były prace nad „Krajowym planem działań w zakresie energii ze źródeł odnawialnych” oraz „Raportem określającym cele w zakresie udziału energii elektrycznej wytwarzanej z OZE, znajdujących się na terytorium RP”. Nie wprowadzono instrumentów wsparcia inwestycji związanych z budową instalacji przetwarzających biogaz rolniczy. Ponadto kontrola NIK wykazała, że system wsparcia dla wytwarzania energii elektrycznej z OZE nie uwzględniał zróżnicowanych kosztów jej uzyskania, jak również nie zapewniał pomocy inwestycyjnej i efektywności ekonomicznej dla instalacji rozproszonych.

Instrumentom wspomagania rozwoju mikroźródeł energii odnawialnej na terenach wiejskich poświęcono panel III. Kazimierz Kujda (prezes zarządu Narodowego Funduszu Ochrony Środowiska i Gospodarki Wodnej) przedstawił rolę NFOŚiGW we wspieraniu rozwoju energetyki obywatelskiej na terenach wiejskich. W tym kontekście zaprezentował między innymi dotychczasowe zaangażowanie finansowe oraz efekty ekologiczne trzech programów priorytetowych: „Wspieranie rozproszonych, odnawialnych źródeł energii Prosument”, „System zielonych inwestycji - biogazownie rolnicze” oraz „BOCIAN - rozproszone, odnawialne źródła energii”. Przybliżył także najważniejsze działania prowadzone w ramach programu „Ogólnopolski system wsparcia doradczego dla sektora publicznego, mieszkaniowego oraz przedsiębiorstw w zakresie efektywności energetycznej oraz OZE”. Zaakcentował przy tym, że realizacja projektu, szczególnie poprzez działalność doradców energetycznych, pomoże w przygotowaniu projektów obywatelskich również na obszarach wiejskich.

Wsparcie finansowe inwestycji związanych z OZE było przedmiotem wystąpienia Stanisława Kluzy (prezesa zarządu Banku Ochrony Środowiska S.A.). Przedstawił on kompleksową ofertę produktową BOŚ Banku, który oferuje szeroką gamę komercyjnych kredytów przeznaczonych zarówno na finansowanie bieżącej działalności, jak i cele inwestycyjne. Bank specjalizuje się w finansowaniu przedsięwzięć 
związanych z ochroną środowiska i gospodarką wodną, w tym w szczególności: gospodarką wodno-ściekową, efektywnością energetyczną, inwestycjami w zakresie zmniejszenia emisji $\mathrm{CO}_{2}$, pyłów i innych zanieczyszczeń powietrza oraz w odnawialne źródła energii. Swoim klientom bank umożliwia skorzystanie z eksperckiej wiedzy ekologów banku, którzy mają wieloletnie doświadczenie w kredytowaniu tego rodzaju inwestycji i pomagają $\mathrm{w}$ wyborze najkorzystniejszych rozwiązań wypracowanych na podstawie sprawdzonych praktyk. Kluza podał też przykłady sfinansowanych przez BOŚ S.A. inwestycji dotyczących wykorzystania OZE.

Na zakończenie tej części konferencji Krzysztof Księżopolski (ekspert Narodowego Centrum Studiów Strategicznych) i Leszek Kuliński (wójt gminy Kobylnica) przedstawili stan infrastruktury sieci energetycznych na terenach wiejskich, zwracając uwagę na ich niską efektywność wynikającą z dużych strat w przesyle oraz wysoki poziom awaryjności (dekapitalizacja, linie napowietrzne na dużym obszarze wytyczone przez lasy, wrażliwość na wahania pogody, a także zmiany klimatyczne). Zaletą sieci rozproszonych są niższe koszty eksploatacyjne, ograniczenie możliwości penetracji rynku energii elektrycznej przez koncerny zagraniczne oraz poprawa bezpieczeństwa energetycznego, a rozmieszczenie źródeł w pobliżu odbiorców zmniejsza straty przesyłu, ogranicza bądź odracza potrzeby rozbudowy sieci, jak również redukuje ewentualne deficyty mocy w szczycie energetycznym. Natomiast odbiorca wykorzystujący niezależne źródła uzyskuje obniżenie kosztów pobieranej energii z jednoczesną poprawą jej jakości i niezawodności dostawy. Dodatkowe korzyści ekonomiczne występują przy skojarzonym wytwarzaniu energii elektrycznej i cieplnej oraz sprzedaży nadwyżek energii do sieci. W zwiększeniu wykorzystania OZE upatruje się też czynnik stymulujący rozwój gospodarczy i społeczny. Firmy inwestujące w zieloną energię wprowadzają nowe technologie, tworzą lokalne rynki pracy, wzmacniają rynek usług, przyczyniając się bezpośrednio do wzrostu innowacyjności danej jednostki terytorialnej, promocji jej wizerunku, a w rezultacie do rozwoju lokalnego. Według Kulińskiego realizacja polityki wsparcia energetyki obywatelskiej wymaga dużego zaangażowania gminnych zasobów ludzkich, technicznych i finansowych, które zniechęcają samorządy do wspierania energetyki obywatelskiej.

Po prezentacji poszczególnych referatów odbyła się dyskusja na tematy związane z źródłami energii odnawialnej. Padały liczne pytania do ministrów rządu RP, przedstawicieli Unii Europejskiej i pozostałych prelegentów. Wskazywano na szanse, ale i bariery rozwoju energetyki obywatelskiej. Całość konferencji podsumował Jerzy Buzek, podkreślając konieczność usunięcia prawnych barier dla ich rozwoju. Ponadto zaznaczył, że warunkiem zintensyfikowania wykorzystania OZE jest pobudzanie indywidualnej inicjatywy oraz budowanie więzi w wymiarze lokalnym i sąsiedzkim. 
